\title{
International Journal of Statistics and Applied Mathematics
}

ISSN: $2456-1452$

Maths 2021; 6(2): 43-47 (C) 2021 Stats \& Maths www.mathsjournal.com Received: 12-01-2021 Accepted: 21-02-2021

\section{Krishna Kanta Parajuli}

Department of Mathematics,

Valmeeki Campus, Kathmandu, Nepal
Corresponding Author: Krishna Kanta Parajuli Department of Mathematics,

Valmeeki Campus, Kathmandu, Nepal

\section{Three separate methods for squaring: A connective prospective on Lilavati, Vedic and Trachtenberg}

\author{
Krishna Kanta Parajuli
}

DOI: https://doi.org/10.22271/maths.2021.v6.i2a.673

\begin{abstract}
In the twelfth-century, Lilavati of Bhascaracharya-II contributed significantly making its occurrence up to the splendid history of mathematics, which has been used as a text-book for mathematics over 800 years in South Asian countries. However, in the nineteenth century, two independently developed mathematical systems namely, Trachtenberg and Vedic system of mathematics were significant all over. This paper mainly accentuates on tracing the connection of Lilavati to Vedic and Trachtenberg system of mathematics. This research is based on a comparison among the three treaties by their mathematical systems on squaring the numbers.

All three mathematical treaties have their separate methods for finding the square. The Lilavati appears to have more or less influence on Vedic and Trachtenberg systems. Moreover, there are many similarities between the Vedic and Trachtenberg mathematical system in squaring the numbers.
\end{abstract}

Keywords: lilavati, vedic, Trachtenberg, squaring

\section{Introduction}

Mathematics carries a great history and is almost in par with human evolution. The History of Mathematics is the man-made science of human interest and reflects the growth of any civilizations perfectly. The history of Mathematics is a powerful tool for every learner as it suggests the evolution of new concepts. History of Mathematics will not only remind us of what we have but will also guide us as a strong future reference. Many mathematicians have contributed their lifetime and work ethics fortifying this beautiful subject.

Bhaskaracarya-II from the twelfth century is one of the important figures regarding the contributions for the glorious history of mathematics. Lilavati, one of his fine creation gathered some remarkable attention as it encompassed some of the unsurpassed, easy, and pertinent procedures for solving many a mathematical problem from different fields. Besides these, Lilavati of Bhaskaracarya-II was the famous leading Mathematics books which have been used as a text-book for the last eight hundred years in south Asian country (Patwardhan et al. 2015, Xv - XXv).

The mathematical tools developed after the upsurge of Lilavati of Bhaskaracarya-II directly or indirectly were certain to be affected by the procedures provided by him. Amongst them, the independently developed concepts of Vedic mathematics and the Trachtenberg system in the nineteenth-century were more likely to get influenced by the methods of Bhaskaracarya-II. In the process of developing mathematics, mental mathematics was also developed by many mathematicians. Among them, two independently developed mathematical systems Trachtenberg and Vedic were remarkable in the history of Mathematics. And this paper mainly emphasizes answering whether these two above mentioned concepts of Vedic mathematics and the Trachtenberg system in the nineteenth-century are affected by Bhaskaracarya-II's conception or not for squaring the numbers.

\section{A glance of three mathematicians and their Mathematics}

Many mathematicians contributed a significant role in making the glorious history of Mathematics. Among them, three mathematicians Bhascaracharya-II, Bharati Krishna Tirthaji, and Jakew Trachtenberg and their mathematics are more relevant for this article. 


\subsection{Lilavati of Bhaskaracarya}

Bhaskaracarya or Bhaskara-II (1114 -1193) was the famous leading Mathematician, Poet, Astronomer of ancient Indian during the twelfth century. Bhaskaracarya wrote his Siddhantasiromani when he was 36. It consists of four parts: Lilavati, Algebra, Planetary motion, and Astronomy (Patwardhan et al. 2015, xix) ${ }^{[14]}$. The first part Lilavati mainly deals with Arithmetic but also contains portions of Geometry, Trigonometry and Algebra. Bhaskaracarya's Lilavati has been used as a text-book for the last eight hundred years in many south Asian countries and is still in practice in many Indian provinces (Patwardhan et al. 2015, xv $-\mathrm{XXv})^{[14]}$.

\subsubsection{Squaring in Lilavati}

There are three methods in Lilavati for squaring a number.

The first method is written in Sanskrit as (Patwardhan et al. $2015,19)^{[14]}$ below.

\section{समद्विघातः कृतिरूच्यतेऽथ स्थाप्योन्त्यवर्गो द्विगुणान्त्यनिघाः । स्वस्वोपरिष्ठाच्च तथाऽपरेऽड्क.स्त्यक्त्वान्त्यमुत्सार्य पुनश्च राशिम् ।।}

\section{(Samadhighaataha kritiruchyateatha sthapyontyawargo} dhigunantyanighnaha,

Swoswoparisthachcha tathaapareankastyakttwantyamutsarya punascha raashim.)

Meaning: First write the square of the extreme left-hand digit on its top. Then multiply the next (i.e., second) digit by the double of the first digit and write the result on the top. Next, multiply the third digit by the double of the first digit and write the result on the top. In this way arrive at the unit's place. Next, cross the first digit and shift the number so formed one place to the right. Then repeat the same procedure. Finally, add all the products written at the top and the sum is the required square (Patwardhan et al. 2015, 19) ${ }^{[14]}$, which is a general method for finding the square of the numbers.

The first method uses the formula $(a+b+c)^{2}=a^{2}+b^{2}+c^{2}+$ $2 \mathrm{ab}+2 \mathrm{bc}+2 \mathrm{ca}$.

Example: To find the square of $396=(300+90+6)^{2}$. By using the above formula, $(396)^{2}=156816$.

In Lilavati, the second and third methods for squaring the numbers is mentioned in Sanskrit verses as (Patwardhan et al. $2015,19)^{[14]}$ follows.

\section{खण्डद्वयस्यभिहितिद्रविनिघ्नी तत्खण्डवर्गेक्ययुता कृतिर्वा । इष्टोनयुग्राशिवधः कृतिः स्यादिष्टस्य वर्गेण समन्वितो वा ।।}

(Khandadhyasyavhihitirdhinighnee tatkhandawargaikyayutta kritirwa, Ishtonyugurashiwadha kritiha sydishtasya wargena samanwito waa.)

Meaning of the first line: Split the given number into two parts. To the sum of the squares of the two parts add twice the product of the two parts. The result is the square (Patwardhan et al. 2015, 20) ${ }^{[14]}$, which is known as the second method of squaring in Lilavati.

By second method, the formula is used as $(a+b)^{2}=a^{2}+2 a b+$ $b^{2}$.

For the square of 396 by the second method, it is written as $(300+96)^{2}$ and getting the result $=156816$.
Meaning of the second line: Add and subtract a suitable of the two numbers thus obtained and add the square of the suitable number chosen above. The result is the required square (Patwardhan et al. 2015, 20) ${ }^{[14]}$, which is known as the third method of squaring in Lilavati.

The Sloka ${ }^{1}$ (in Sanskrit) command: The number is added and subtracted to the given number, multiply them and add the square of the Ista ${ }^{2}$. If $x$ is the number to be squared and choose the Ista number in such a way that $(x-a)$ and $(x+a)$ can be easily multiplied.

Then $x^{2}=(x-a)(x+a)+a^{2}$.

Example: To find the square of 396 ,

Here, 4 is the best Ista number, such that $(396-4) \times(396+4)$ can be multiplied easily.

Then, $(396)^{2}=(396-4) \times(396+4)+4^{2}=392 \times 400+16=$ $156800+16=156816$.

\subsection{Bharati Krishna Tirthaji}

A very renowned cultured personality of India, Jagadguru Sankaracharya Sri Bharti Krishna Tirthaji (1884 -1960) was the glorious and divine person. He is well known for his formulation and reconstruction of Vedic Mathematics from certain Sanskrit text Veda. According to him, the Vedic system is based on Sixteen Sutras and an equivalent number of sub-sutras cover all branches of mathematics, pure and applied. Vedic Mathematics was formulated and reconstructed by Tirthaji in the time of 1911-1918, was only published in 1965 after his death in 1960 (Tirthaji 2015, xxiii - xxxi). Vedic Mathematics also relates to mental calculations.

\subsubsection{Squaring in Vedic Mathematics}

The Vedic method consists of two methods for squaring the number, they are specific and general. There are four methods including specific and general in Vedic Mathematics to find the square of a number. Among these methods, the first two methods belong to specific parts and the second two methods belong to general parts. These methods can be mentioned as (Tirthaji 2015; Singhal 2014; Thakur 2013).

1. Ekadhikena Purvena (एकाधिकेन पूर्वेण) ${ }^{3}$

2. Yavadunam Tavadani Kritya Varganea Yojayet (यावदूनम तावदूनिकृत्य वर्गेण योजयेत्) ${ }^{4}$

3. Dwanda Yoga (द्वन्दू योग) ${ }^{5}$

iv) Urdhya Tiryagbhyam (उध्वतिर्यगभ्याम्) ${ }^{6}$

${ }^{1}$ Sloka(श्लोक) = A couplet of Sanskrit Verse.
${ }^{2} \mathrm{Ista}($ ईश्ट) = Deviation
${ }^{3}$ Ekadhikena Purvena (एकाधिकेन पूर्वेण) = (One less than the previous one)

4 Yavadunam Tavadani Kritya Varganea Yojayet (यावदूनम तावदूनिकृत्य वर्गेण योजयेत्) = (Whatever the extent of its deficiency, lessen it further to that extent and set up the square of deficiency)

${ }^{5}$ Dwanda Yoga (द्वन्द्व योग $)=($ Duplex Combination $)$ 
(i) Ekadhikena Purvena is used to deal with the square numbers ending in particular digit 5. Mathematically, it can be written as:

$(\mathrm{x} 5)^{2}=\mathrm{x} \times(\mathrm{x}+1) / 5^{2}$.

Example: $(75)^{2}=7 \times(7+1) / 5^{2}=56 / 25=5625$

$\therefore \quad(75)^{2}=5625$.

(ii) Yavadunam method works for the numbers to be squared is either near to the base $10^{\mathrm{n}}$ or $10 \mathrm{n}$, where $\mathrm{n}$ is an integer (Thakur 2013).

When the numbers near to the base $10^{\mathrm{n}}$.

The answer is arrived in two parts: LHP \& RHP

LHP $=$ Number + Deviation $\&$ RHP $=$ Square of deviation.

Example: To find the square of 107 ,

$\mathrm{LHP}=107+7=114, \mathrm{RHP}=7^{2}=49$

$(107)^{2}=11449$.

Example: $(112)^{2}=112+12 /(12)^{2}=124 / 144=12544$.

When the number near to $10 \mathrm{n}$. The answer in LHP $=($ Number to be squared + Deviation) $\times$ Sub-base

RHP $=$ Square of the deviation

Example: $(58)^{2}=(58-2) \times 6 /(-2)^{2}=336 / 4=3364$

Example: $(76)^{2}=(76+6) \times 7 / 6^{2}=574 / 36=5776$

(iii) Above two methods are useful for special types of numbers only, but there is another method i.e. Dwanda Yoga (or Duplex) which is general method, so it is applicable for all types of numbers.

For this, we need to know about the duplex of different digits numbers, which is denoted by $\mathrm{D}$.

Duplex of 1-digit number $=$ Square of that number

i.e. $D(a)=a^{2}$

Similarly, $\mathrm{D}(\mathrm{ab})=2 \mathrm{ab}, \mathrm{D}(\mathrm{abc})=2 \mathrm{ac}+\mathrm{b}^{2}$

$\mathrm{D}(\mathrm{abcd})=2 \mathrm{ad}+2 \mathrm{bc}, \mathrm{D}(\mathrm{abcde})=2 \mathrm{ae}+2 \mathrm{bd}+\mathrm{c}^{2} \&$ so on (Tirthaji 2015).

Rules for squaring with the help of duplex in stepwise (Thakur 2013; Singhal 2014)

- Start with the duplex of the right-most digit.

- Form adding a digit and finding their duplex.

- When taken all the digits then leaving digits from the right and go on till we are on the left-most digit.

- Writing the answer by keeping only one digit in each separator.

Example: $(453)^{2}=\mathrm{D}(4) / \mathrm{D}(45) / \mathrm{D}(453) / \mathrm{D}(53) / \mathrm{D}(3)$

6 Urdhya Tiryagbhyam (उध्वतिर्यगभ्याम्) $=$ (Vertically and
$=16 / 2 \times 4 \times 5 / 2 \times 4 \times 3+5^{2} / 2 \times 5 \times 3 / 9$

$=16 / 40 / 49 / 30 / 9=205209$

(iv) The method of squaring a number by Urdhava-Tiryak method is nothing new but it is the same as the multiplication of two numbers by the same Vedic method.

\subsection{Jakow Trachtenberg}

Russian Jewish Engineer Jakow Trachtenberg (1888 - 1953) invented a mathematical system when he was sentenced to prison (Cutler et al. 2008, 7 - 17). He was sentenced as he was against the philosophy of Adolf Hitler during the time of the second world war. He was mostly known for the development of mental calculation techniques which today is widely known as the Trachtenberg method. The Trachtenberg system was developed around 1944-1945. Trachtenberg introduced his methods and started to experiment on his students in Switzerland in 1950 (Cutler et al. 2008, 7 - 17). His system was easy and still followed by many of the people. The efforts he applied is remarkable and is comparable to that of Bharati Krishna Tirthaji.

\subsubsection{Squaring in Trachtenberg System}

Trachtenberg's mathematical system consists of two types, special and general. The specific type of system is restricted by special conditions whereas general doesn't consist of any type of barrier or conditions, i.e. general is applicable for every type of number. For squaring the numbers, the Trachtenberg system includes two special cases of numbers (Cutler 2008, 188 - 197). The first case related to the numbers in which the unit digit number is 5 , like 45 or 65 or 85 , etc. and the second case related to the numbers in which the tenth digit number is 5 , like as: 56 or 58 or 59 , etc.

For the first case: Taking an example of 65 for squaring the first case numbers. The result consists of two parts: LHP and RHP such that RHP is always 25 (i.e. square of unit place number) and LHP is the multiplication of 6 and $(6+1)$ i.e. 42 . Hence the square of 65 is 4225 .

For the second case: Taking an example of 58 for squaring the second case numbers. This case also consists of LHP and RHP parts. RHP is the square of unit digit number i.e. 64 and RHP is obtained by $25+$ unit digit number i.e. $25+8=33$. Hence the square of 58 is 3364 .

Note: Above cases can be extended for a further number of digits.

The specific are those which are fast and effective but can be applied only to a particular case of numbers. But, the general pattern of squaring by the Trachtenberg system is applicable in all the cases of all types of numbers. To clarify the idea for squaring the numbers in general cases, it should be better to take an example for illustration.

For two-digits number: For squaring the two-digits number $a b=(a b)^{2}=(10 a+b)^{2}=100 a^{2}+20 a b+b^{2}$. But this result can be obtained mentally by Trachtenberg mathematical system as described stepwise (Cutler et al. 2008, 190 - 193) below. Let's forward the number 73 for an example with stepwise.

Crosswise) 


\begin{tabular}{|c|c|c|c|}
\hline Steps & Stepwise obtained numbers in squaring of 73. & Operation Process & Remarks \\
\hline $1^{\text {st }}$ & 09 & Square of RHN $=09$ & Write 9 and Carry-over 0 \\
\hline $2^{\text {nd }}$ & ${ }^{4} 29$ & $2 *$ LHN*RHN + carry-over $0=42$ & Write 29 and Carry-over 4 \\
\hline $3^{\text {rd }}$ & 5329 & Square of RHN + carry-over 4 =53 & place 53 in the right-hand part of 29. \\
\hline \multicolumn{2}{|r}{} \\
\hline
\end{tabular}

Here, $\mathrm{LHN}=7$ and $\mathrm{RHN}=3$

For Three-digits Number: For squaring the three-digits number $a b c=(a b c)^{2}=(100 a+10 b+c)^{2}=10000 a^{2}+100 b^{2}+$ $c^{2}+2000 a b+20 b c+200 a c$. But this result can be obtained mentally by Trachtenberg mathematical system as described stepwise (Cutler et al. 2008, 193 - 197) below. Lets forward the number 428 for an example with stepwise.

\begin{tabular}{|c|c|c|c|}
\hline Steps & $\begin{array}{c}\text { Stepwise obtained } \\
\text { numbers in } \\
\text { squaring of } \\
428 \\
\end{array}$ & Operation process & Remarks \\
\hline $1^{\text {st }}$ & 0784 & $\begin{array}{c}\text { Square of last 2-digits } 2 \\
\& 8\end{array}$ & $\begin{array}{l}\text { Obtained by the } \\
\text { same process of 2- } \\
\text { digits number. }\end{array}$ \\
\hline $2^{\text {nd }}$ & $\begin{array}{c}0784 \\
+64 \\
7184\end{array}$ & $2 * \mathrm{LHN} * \mathrm{R}$ & $\begin{array}{c}\text { Add } 64 \text { from left } \\
\text { such that } 07+64 \\
=71\end{array}$ \\
\hline $3^{\text {rd }}$ & $\begin{array}{c}1 \quad \begin{array}{c}6 / 16 / 718 \\
4\end{array} \\
=16 / 1 \underbrace{137184} \\
=183184\end{array}$ & $\begin{array}{c}\mathrm{LHP}=\text { Square of } \mathrm{LHN} \\
=4^{2}=16, \mathrm{MP}= \\
2 * \mathrm{LHN} * \mathrm{MN}=2 * 4 * 2= \\
16 \\
\mathrm{RHP}=\text { Result from } 2^{\text {nd }} \\
\text { step }=7184\end{array}$ & $\begin{array}{c}1 \text { st.line }=6+7= \\
13={ }^{1} 3 \text { (carry over } \\
1) \\
2^{\text {nd }} \text { line }=1+6+ \\
\text { carry over }=8 \\
3^{\text {rd }} \text { line }=\text { the last } \\
\text { Result }\end{array}$ \\
\hline \multicolumn{4}{|c|}{ erefore, $(428)^{2}=18318$} \\
\hline
\end{tabular}

Here, $\mathrm{LHN}=4 ; \mathrm{MN}=2 ; \mathrm{RHN}=8$

Note: $\mathrm{RHN}=$ Right Hand Number; LHN = Left Hand Number; MN $=$ Middle Number.

LHP = Left Hand Part; MP = Middle Part; RHP = Right Hand Part

\section{Findings}

Both the Vedic and Trachtenberg system was used and invented in the same period, however, are independent to each other and none has their communicational influence upon each other. The Trachtenberg system was in its early developing phase in eastern Europe meanwhile, the Vedic mathematics system was also under development in the south Asian society. Trachtenberg introduced his methods and started to experiment with his students. Meanwhile, Vedic methods though was formulated by Tirthaji in the time of 1911-1918, were only published later after his death.

Procedurally, Ekadhikena Purvena formula of Vedic mathematics is the same as the first special cases of the Trachtenberg mathematical system for squaring. The general method of the Trachtenberg system is more or less equivalent to the Urdhva Tiryagbhyam formula of Vedic mathematics for squaring. It is noted that: Urdhya Tiryagbhyam formula is also a general method of multiplication in Vedic mathematics. There is also the similarity in between the third method of squaring of numbers of Lilavati and the second

method of Vedic Mathematics. i.e. Yavadunam Tavadani. In the Yavadunam method, there is a deviation that is similar to the Ista in Lilavati's method for squaring the numbers. But the whole process of finding the square is slightly different between them. In the Yavadunam method, the deviation is based on the number either by $10^{\mathrm{n}}$ or $10 \mathrm{n}$, whereas in Lilavati, Ista is taken in such a way that $(x-a)$ and $(x+a)$ can be multiplied easily. In Lilavati, the second method is not useful for any large number whereas the third method is used only for special types of numbers.

\section{Conclusions}

From the above shreds of evidence, it is quite clear that the both Vedic and Trachtenberg system are unaffected communicationally by each other. However, in squaring the number, both methods do carry some similar procedures. It attests that they are interrelated in some major aspects. Though, both the Vedic Mathematics and Trachtenberg system were developed independently, they have similarities in basic mathematical operations like as observed in squaring. Trachtenberg system is confined within the basic concepts and operation on arithmetic meanwhile, the Vedic Mathematics approaches to broader fields.

The mathematical tools developed after the upsurge of Lilavati of Bhaskaracarya-II directly or indirectly were certain to affect the later developed procedures. And it has been evident that the similarity in few steps on squaring numbers in Lilavati and Vedic system is comparable and Vedic mathematics is quite related to the Lilavati for squaring. Meanwhile, the direct interrelation between the procedures to find squares of a number in Lilavati and the Trachtenberg system is not that prominent.

In modern mathematical systems, people require a calculator for their numerical calculations. Various investigation shows that calculator dependency deteriorates the academic performance of the learner in primary level education. Therefore, the practice of Vedic and Trachtenberg systems may be very fruitful for mental calculations of basic mathematical operations.

\section{Acknowledgement}

I would like to express my genuine thanks to my Ph.D. supervisor, Prof. Dr. Kanhaiya Jha, Kathmandu University for his marvelous support with strong and proper academic guidance for encouraging me to develop my thoughts and helping to complete this article.

\section{Disclosure Statement}

Krishna Kanta Parajuli, the author hereby declares that there is no potential conflict of interest.

\section{References}

1. Ann Cutler and Rudolph Mcshane, The Trachtenberg speed system of basic mathematics (English edition), New Delhi, India: Asia publishing house, $34^{\text {th }}$ impression, 2008, ISBN 0-285-62916-6.

2. B Mohan, Ganitka Itihas, Lakhnou, Up, India: Hindi samiti suchana bibhag, 1965.

3. Bharati Krishna Tirthaji, Vedic mathematics, New Delhi, India: Motilal banarsidass publishers Pvt Ltd, 2015, ISBN 978-81-208-0164-6

4. Bhaskaracharya, Bhascaracharya pranitam bijganitam, Choukhamba Bhawan, India: Avyktaganita pransamsa, 1992.

5. D Sengupta, 'Approach towards designing fast arithmetic circuits using ancient Vedic mathematics sutras', Jadavpur university: A published $\mathrm{Ph} \mathrm{D}$ thesis by 
shodhganga, a reservoir of Indian theses, 2016. http://sodhganga.inflibnet.ac.in

6. James Glover, Vedic mathematics for schools - 1,2 and 3, New Delhi, India: Motilal banarasidass publishers Pvt Ltd, 2002. http:// www.vedicmaths.org

7. Parajuli KK, 'A mental mathematics-trachtenberg system', Sodh research journal. Kathmandu, Nepal: Nepal professor association, Nepal Sanskrit University 2012, 218-224.

8. Parajuli KK, Jha K, Acharya SR, Maskey SM. 'A research on efficacy of teaching Vedic mathematics in school level', International journal of mathematical sciences and engineering applications, Ascent publication, Pune, India 2020;14(1):35-41. ISSN 09739424. http://www.ascent.journals.com/ijmsea

9. Parajuli KK, Jha K, Acharya SR, Maskey SM, 'Connection of paravartya sutra with vedic and non-vedic mathematics', proceeding of $4^{\text {th }}$ international Vedic mathematics conference, IAVM publishing, 6 Barnfield gardens, Kingstone, Upon-Thames, UK: 2020, 20-25, ISBN 978-1-9161247-5-2. www.instavm.org

10. Kenneth William, The natural calculator, Scotland, UK: inspiration books, 2009.

11. http:// www.vedicmaths.org

12. Kenneth Williams, Discover Vedic mathematics, Scotland, UK: inspiration books, 2019. http:// www.vedicmaths.org

13. Kenneth Williams, Vedic mathematics teacher manual 1, 2, and 3, Scotland, UK: inspiration books, 2019. http:// www.vedicmaths.org

14. Krishnaji Shankara Patwardhan, Somashekhara Amrita Naimpally and Shyam Lal Singh, Lilavati of Bhaskaracarya, New Delhi, India: Motilal banarasidass publishers Pvt Ltd, fourth reprint, 2015, ISBN 978-81208-1777-7

15. Rajesh Kumar Thakur, Essential of Vedic mathematics, New Delhi, India: Rupa publications Pvt Ltd, sixth impression, 2016. ISBN 978-81-291-2374-9

16. Vaidya SA. 'The contribution of Vedic mathematics in advance calculus': Shri jagadishprasad jhabarmal tibarewala university, a published $\mathrm{Ph} \mathrm{D}$ thesis by shodhganga, a reservoir of Indian theses, 2019. http://sodhganga.inflibnet.ac.in

17. Vandana Singhal, Vedic mathematics for all ages, New Delhi, India: Motilal banarasidass publishers Pvt Ltd, second edition, 2014, ISBN 978-81-208-3230-5. 